GA-A15377

UC-77

\title{
THE USE OF SPIKANTS IN HTGR FUEL AND THEIR EFFECT ON COSTS
}

\author{
by \\ LIONEL H. BROOKS
}

\author{
Prepared under \\ Contract DE-AT03-76ET35300 \\ for the San Francisco Operations Office \\ Department of Energy
}

\section{GENERAL ATOMIC COMPANY}




\section{DISCLAIMER}

This report was prepared as an account of work sponsored by an agency of the United States Government. Neither the United States Government nor any agency Thereof, nor any of their employees, makes any warranty, express or implied, or assumes any legal liability or responsibility for the accuracy, completeness, or usefulness of any information, apparatus, product, or process disclosed, or represents that its use would not infringe privately owned rights. Reference herein to any specific commercial product, process, or service by trade name, trademark, manufacturer, or otherwise does not necessarily constitute or imply its endorsement, recommendation, or favoring by the United States Government or any agency thereof. The views and opinions of authors expressed herein do not necessarily state or reflect those of the United States Government or any agency thereof. 


\section{DISCLAIMER}

Portions of this document may be illegible in electronic image products. Images are produced from the best available original document. 
GA-A15377

UC-77

\title{
THE USE OF SPIKANTS IN HTGR FUEL AND THEIR EFFECT ON COSTS
}

by

LIONEL H. BROOKS

\author{
Prepared under \\ Contract DE-AT03-76ET35300 \\ for the San Francisco Operations Office \\ Department of Energy
}

GENERAL ATOMIC PROJECT 6434

This report was prepared as an account of work sponsored by the United States Government Netther the United States nor the United States Department of

Energy, nor any of their employees, nor any of their

Entractors, subcontractors, or their employees, makes

cony mer implied, or assumes any legal

ing accuracy, compieteness

or usefuless of any information, apparatus, product or

or usefs dis use would no

infringe privately owned nghts

DATE PUBLISHED: MAY 1979 


\section{$\underline{A} \underline{B} \underline{S} \underline{T} \underline{R} \underline{A} \underline{C} \underline{T}$}

The costs of fresh fuel fabrication have been estimated for flowsheets that have spikant added (Co-60) at various points. The costs are compared with refabricated and fresh fuel fabrication costs.

It is shown that the costs increase as the spikant is added nearer to the plant feed point. The least cost is achieved by adding a detachable spikant to the finished fuel element. The highest cost is incurred when the spikant is fed in with the plant feed. This cost is greater than that for refabricated fuel because extra process cells are necessary to prepare the spikant and, in addition, the gamma flux from the Co-60 is much greater than from U-232 and greater precautions have to be taken. 
TABLE OF CONTENTS

1.0 INTRODUCTION................................ 1

2.0 SPIKANT ADDITION.......................... 5

2.1 Fuel/Cobalt Mix.......................... 5

2.2 Spikant Attached Separately.................. 5

3.0 CHOICE AND QUANTITY OF SPIKANT................... 6

4.0 FLOWSHEETS............................... 7

4.1 Intimately Mixed........................ 7

$4.1 .1 \mathrm{vO}_{2}$ and Cobalt......................... 7

4.1 .2 Cobalt in Shim Particles................. 9

4.1.3 Cobalt in Special Rods (Random)............ 9

4.1.4 Cobalt in Special Rods in One Fuel Hole...... 12

4.2 Spikant Attached Separately.................. 12

$5.0 \quad$ costs...................................... 15

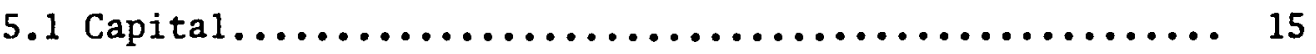

5.2 Operating............................... 15

5.3 Combined Costs........................... 15

6.0 CONCLUSIONS $\ldots \ldots \ldots \ldots \ldots \ldots \ldots \ldots \ldots \ldots \ldots \ldots \ldots \ldots \ldots \ldots \ldots \ldots$

7.0 REFERENCES................................ 21

APPENDIX $1 . \ldots \ldots \ldots \ldots \ldots \ldots \ldots \ldots \ldots \ldots \ldots \ldots \ldots \ldots \ldots \ldots \ldots \ldots \ldots$ A-1 


\section{LIST OF FIGURES}

1-1 High Enriched Uranium-Thorium Generic Fuel Cycle..... 2

1-2 HTGR Fuel Fabrication and Refabrication Flow Diagrams. 3

1-3 HTGR Standard Fuel Element................... 4

4-1 HTGR Fuel Fabrication Flow Diagram Using Co-60 Mixed with Feed $U_{2} \ldots \ldots \ldots \ldots \ldots \ldots \ldots \ldots \ldots . \ldots . \ldots$

4-2 HTGR Fuel Fabrication Flow Diagram Using Cobalt-Loaded Shim Particles..................... 10

4-3 HTGR Fuel Fabrication Flow Diagram Using Special Cobalt Rods at Random................. 11

4-4 HTGR Fuel Fabrication Flow Diagram Using Special Cobalt Rods in Specific Fuel Holes.......... 13

4-5 HTGR Fuel Fabrication Using Attached Spikant Flow Diagram........................ 14

A-1 Gamma Flux Equivalent to $1 \mathrm{R} / \mathrm{h}$ as a Function of Gamma Energy............................... A-2 


\section{LIST OF TABLES}

5-1 Summary of Capital and Operating Costs by

Process in $\$$ Millions......................... 16

5-2 Summary of Total Capital and Operating Costs........ 19 


\section{$1.0 \quad$ INTRODUCTION}

The addition of gamma spikants to deter diversion of fresh or refabricated fuel is technically feasible, however spikants would increase the fabrication costs. The lowest costs would be for fabricating fresh fuel, reprocessing, and refabricating recycle fuel, while making use of the self-protective features of U-232 in the recycled fuel. Figure 1-1 illustrates the process flow diagram for the generic reference fuel cycle. Figure 1-2 illustrates the more detailed fabrication and refabrication steps which form the basis for judging the feasibility for adding spikants and for making the cost comparisons.

All of the alternative methods for adding spikants are based upon utilizing the standard HTGR fuel element, (1) illustrated in Figure 1-3. 


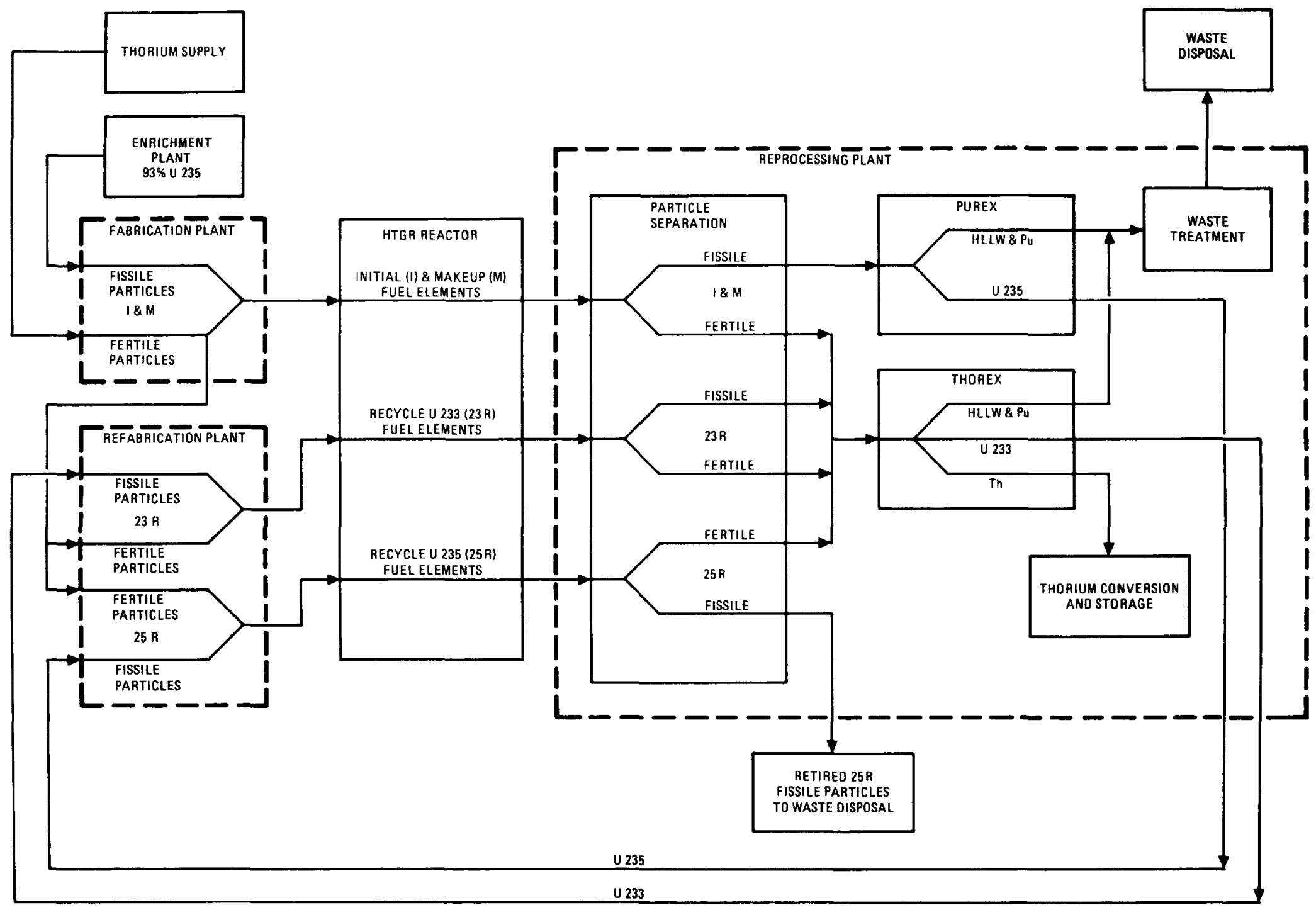

Fig. 1-1. High enriched uranium-thorium generic fuel cycle 


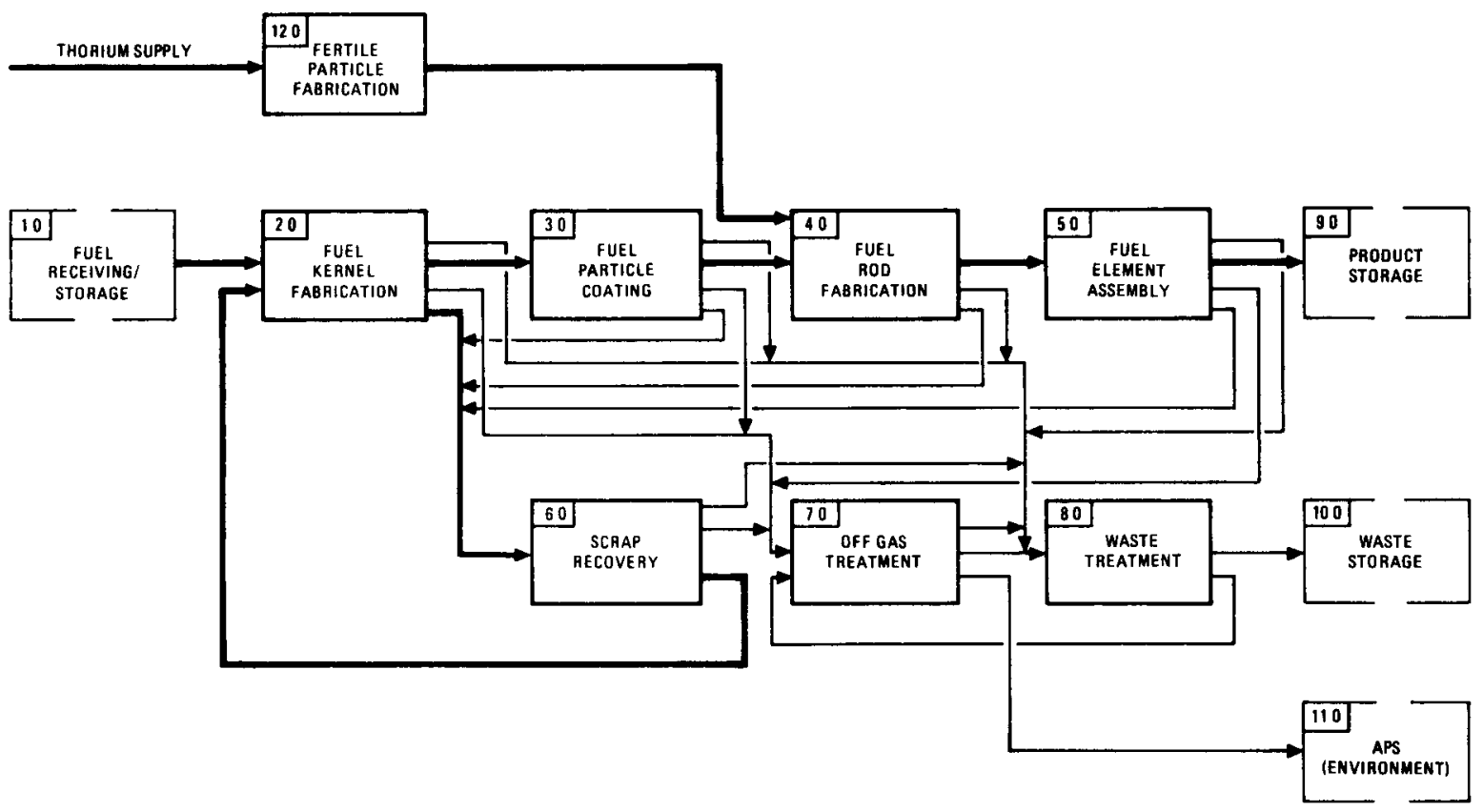

Fig. 1-2. HTGR fuel fabrication and refabrication flow diagrams 

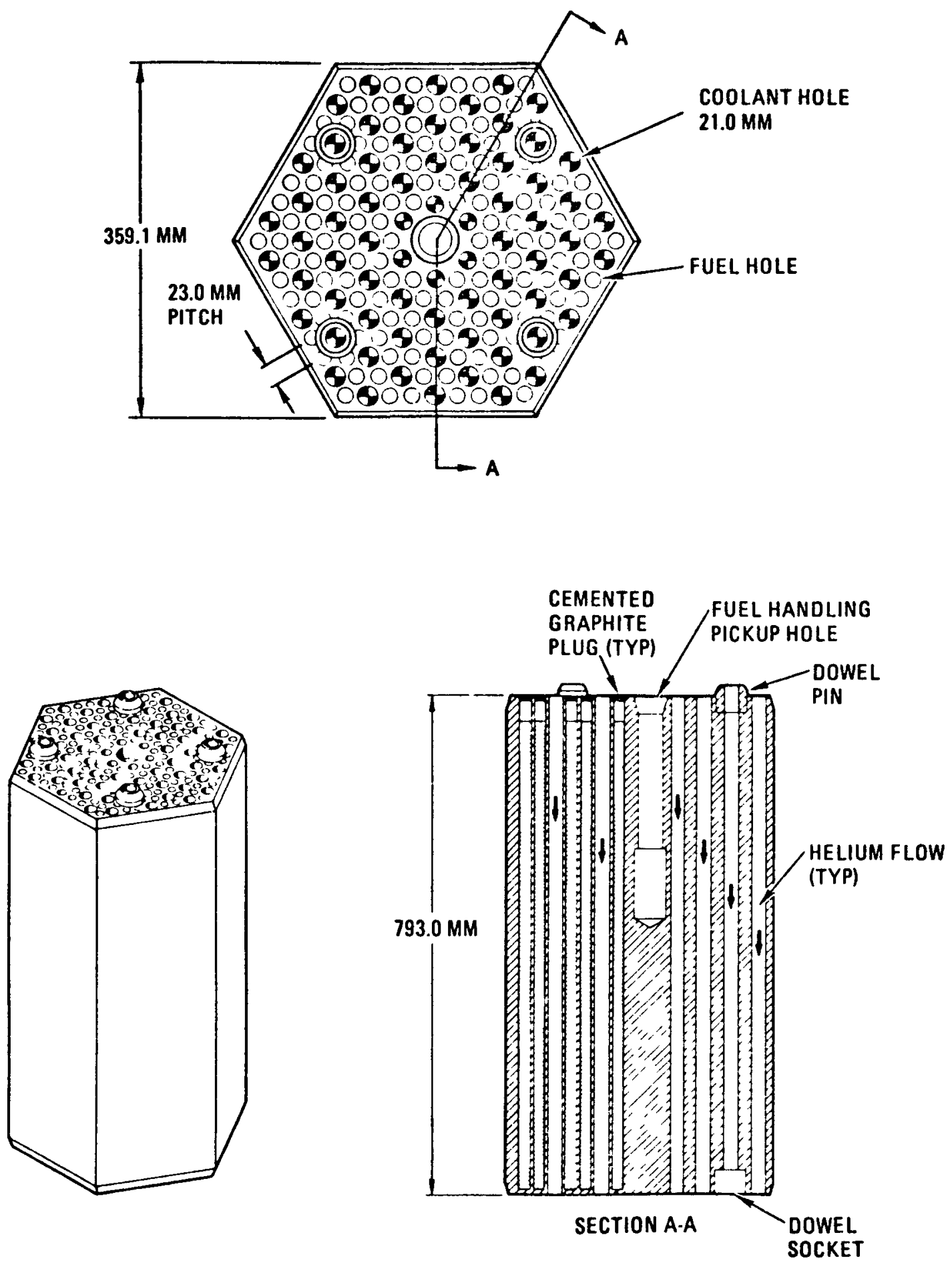

Fig. 1-3 LHTGR standard fuel element 


\subsection{SPIKANT ADDITION}

\section{$2.1 \quad$ Fuel/Cobalt Mix}

This method involves mixing the spikant with the fuel in such a way that a diverter would have to spend a considerable amount of time until the uranium was free of the spikant. The stage of incorporation of the spikant could be as follows:

1) Mixed with the $\mathrm{UO}_{2}$.

2) Coated with pyrocarbon and added as part of the shim particle load in the rod.

3) Coated and fabricated into special rods which are located at random in the fuel holes along with the fuel rods.

4) Alternatively, as in 3) but are placed in reserved fuel holes.

\subsection{Spikant Attached Separately}

In this case, the spikant is enclosed in special capsules which are attached to the fuel element just before the packaging operation. The attachment is removed during inspection as it is accepted by the utility. 


\subsection{CHOICE AND QUANTITY OF SPIKANT}

Co-60 is a likely material because it has a strong gamma source, has a favorable half life, is chemically stable, is easily made by irradiating cobalt and the raw material is plentiful. Cobalt-60 is manufactured by irradiating cobalt in a neutron flux and, in an HTGR, the concentration of Co-60 increases at approximately $2 \%$ per year. The specific activity of Co-60 is $1305 \mathrm{Ci} / \mathrm{g}$.

Another method of incorporating spikant is to retain 0.1 $0.2 \% \mathrm{Zr}, \mathrm{Nb}$, and $\mathrm{Ru}$ in the recycle uranium stream at the reprocessing plant and feed the fresh U-235 through the refabrication plant. This automatically confers sufficient gamma activity to deter diversion of the fuel.

The difference between using the recycle uranium (containing fission product spikant) and Co-60 is that the former provides no options -- the fabrication plant becomes a refabrication plant. With Co-60, however, the point in the fabrication processes at which it is added can be chosen.

The quantity of Co-60 required to give a dose rate of $10 \mathrm{R} /$ hour (intimately mixed) at one meter from the surface of a fuel element is $21 \mathrm{Ci}$; (i.e., $0.016 \mathrm{~g}$ ), and $2100 \mathrm{Ci}$ (i.e., $1.6 \mathrm{~g}$ ) provides a dose rate of $1000 \mathrm{R} /$ hour (attached).

The method of derivation is given in Appendix 1. 


\subsection{FLOWSHEETS}

A number of alternate means for placing Co-60 in fuel elements have been considered, and are described in terms of the

process flow sheets.

\subsection{Intimately Mixed}

\subsection{1 $\mathrm{UO}_{2}$ and Cobalt}

The flowsheet showing the effect on the plant because of adding cobalt to $\mathrm{UO}_{2}$ is illustrated in Figure $4-1$. The process cells that handle the feed have to be remote. It is seen that in addition to all the cells downstream being remotely operated, the service streams have also to be shielded.

In addition, added facilities are required:

1) The cobalt has to be processed to a form which is suitable for addition to the fuel kernels. The exact form has not been decided, but will presumably be either oxide or metal of appropriate particle size and handling quality.

2) Special transport is required to bring the gamma-active material from the production plant to the fabrication plant. Heavy shielding is required, and it is assumed that numerous journeys per year will be necessary. 


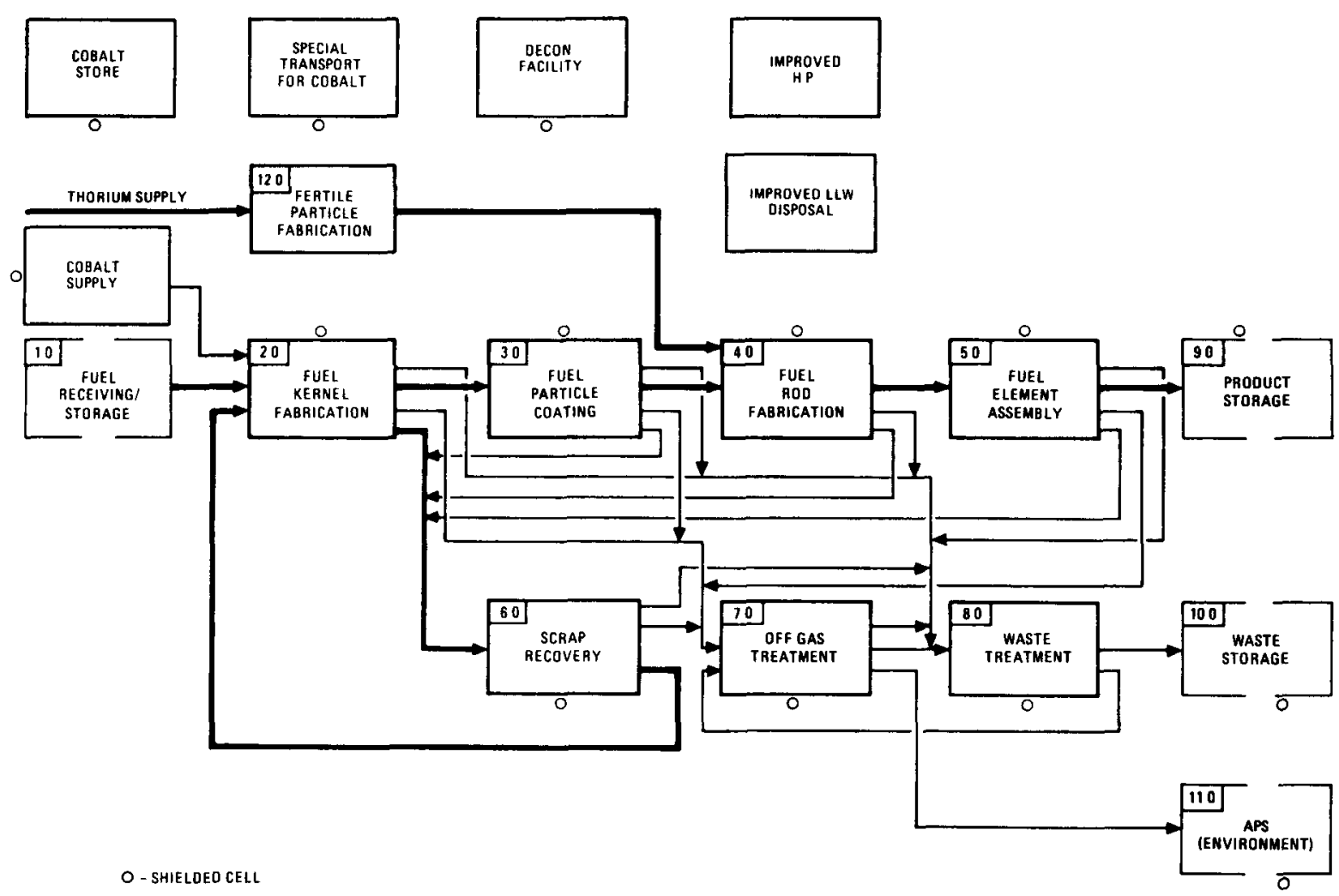

Fig. 4-1. HTGR fuel fabrication flow diagram using Co-60 mixed with feed $\mathrm{UO}_{2}$ 
3) A small but special decontamination facility is required to clean up the containers and equipment that are contaminated with cobalt. Because the flux level is higher for cobalt that U-233 (containing U-232), the uranium decontamination cell will not be adequate.

4) The Health Physics arrangements for the refabrication plant will have to be improved to ensure the detection of Co-60 in the environment.

5) The low-level waste generated during operations will have a higher gamma flux although the quantity will probably not increase. It is probable that special arrangements will have to be made to either contain and dispose of the waste more carefully or process it to reduce the flux before disposal.

\subsubsection{Cobalt in Shim Particles}

The flowsheet is shown in Figure 4-2. The shim particles have to be prepared remotely, and the plant has to be remotely operated from fuel rod fabrication onward. Service streams have to be remotely operated.

\subsubsection{Cobalt in Special Rods (Random)}

The flowsheet is shown in Figure 4-3. The cobalt is fabricated into rods in a special remote cell and loated at random into the fuel elements remotely. The service streams do not need to be remote, but an out-of-spec fuel element has to be disassembled remotely and the cobalt rods removed before the scrap can be recycled. The recovered rods can be either stored as waste or re-used. Because the risk of spread of contamination is much reduced, there is no 


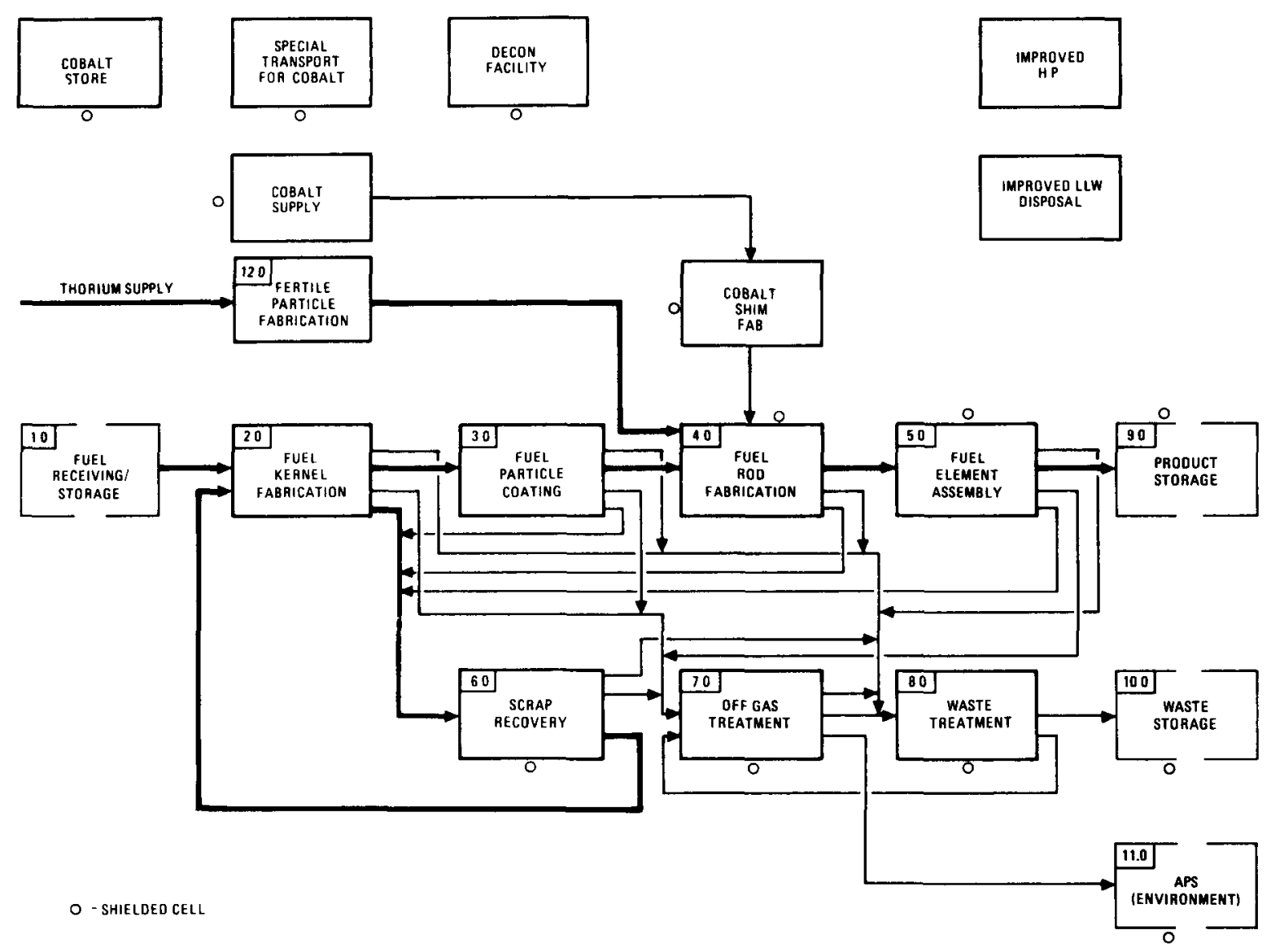

Fig. 4-2. HTGR fuel fabrication flow diagram using cobalt loaded shim particles 


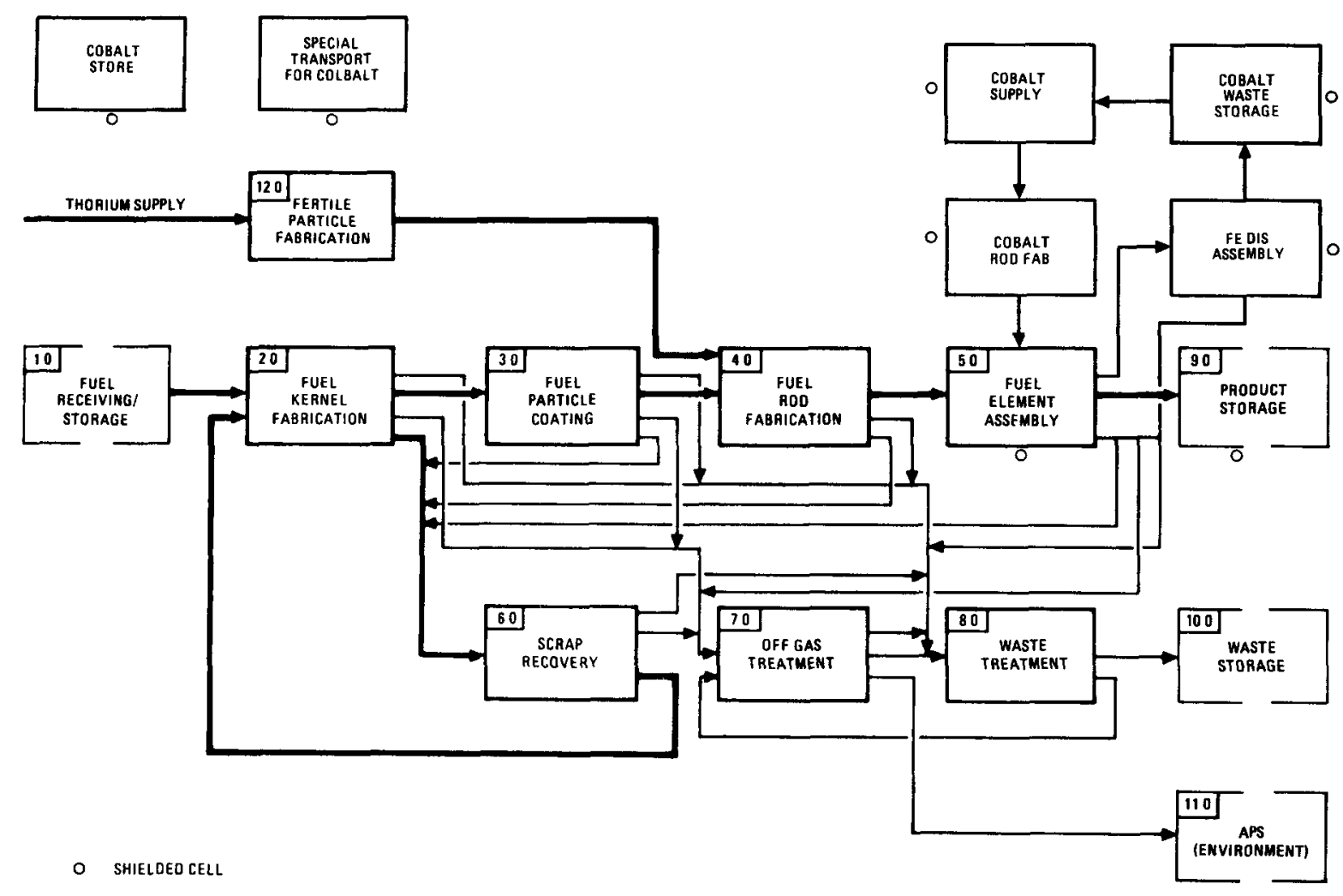

Fig. 4-3. HTGR fuel fabrication flow diagram using special cobalt rods at random 
need for improved health physics, a decontamination facility, or improved low-level waste disposal.

\subsubsection{Cobalt in Special Rods in One Fuel Hole}

The flowsheet is shown in Figure 4-4. The advantage of this system is that the fuel rods would be loaded non-remotely and the cobalt rods would be loaded remotely afterwards in a special fuel hole. If disassembly were required, the cobalt rods would be removed first remotely and the remainder of the fuel element disassembled non-remotely.

\subsection{Spikant Attached Separately}

The flowsheet is shown in Figure 4-5. The advantage of this system is that fabrication processes are not modified at all. The fuel element is prepared in the usual way and the spikant is added after the fuel element has been accepted by QC.

The spikant could be placed in the fuel element by means of a cage arrangement in which hardened steel rods pass through the outer coolant holes and into a locking plate at each end. The large quantity of cobalt ( $100 \mathrm{~g}$ containing $2 \mathrm{~g}$ Co-60) could, for example, be contained in tubes that are placed in the inner coolant holes. Arranged in a manner such as this, the cobalt is easy to remove with suitable tools in the shielded cell at the generating plant, but hazardous to remove without the tools and shielding. 


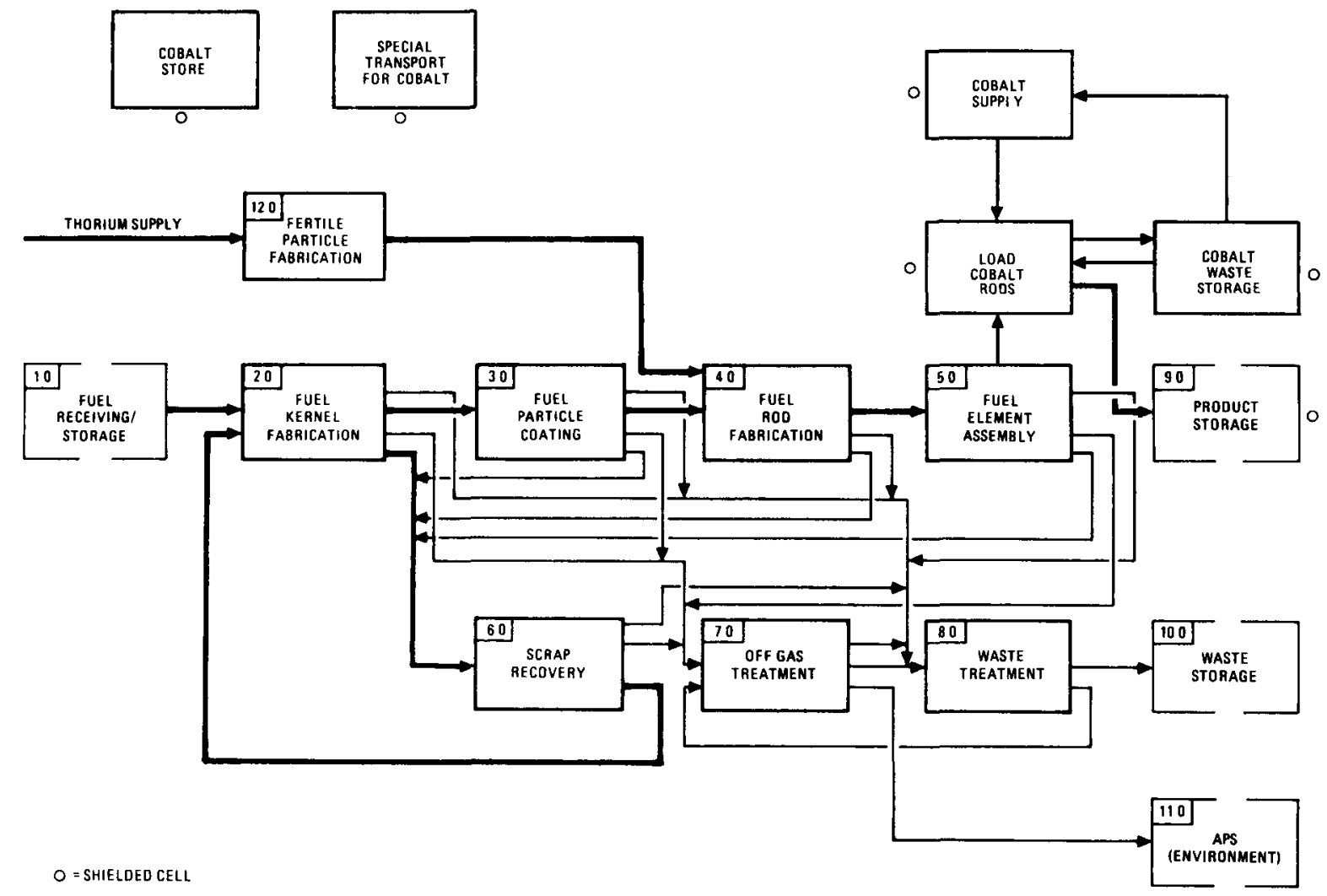

Fig. 4-4. HTGR fuel fabrication flow diagram using special cobalt rods in specific fuel holes 


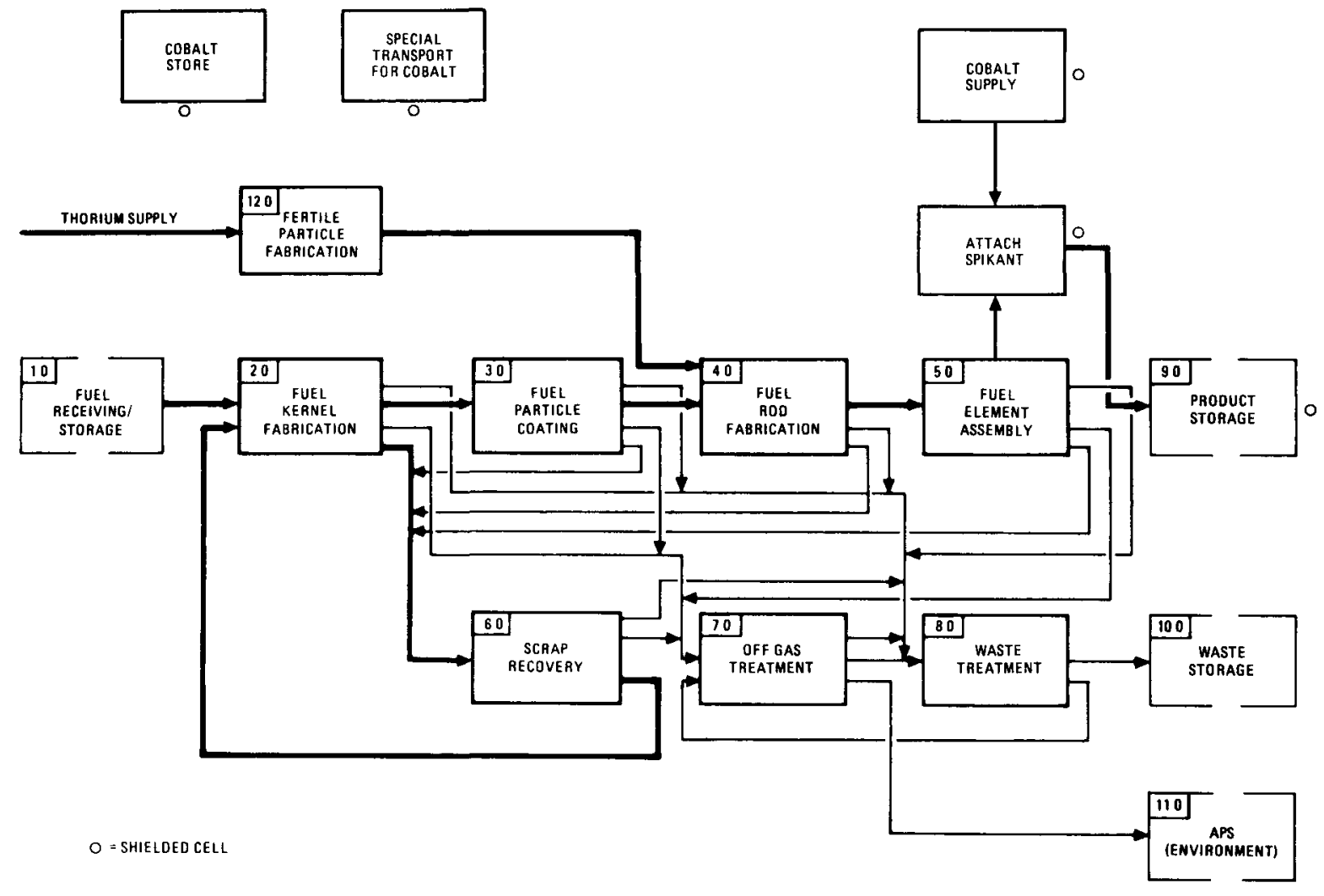

Fig. 4-5. HTGR fuel fabrication using attached spikant flow diagram 


\section{$5.0 \quad$ COSTS}

\section{$5.1 \quad$ Capital}

It is seen from Figures 4-1 through 4-5 that the complexity of the plant increases as the spikant is added further upstream. The most complex plant is that which has the spikant added to the U-235 feed as it passes into the fuel kernel fabrication cell. The fuel then becomes more gamma-potent than U-233 (containing U-232) and has to be treated, if anything, with more care and respect. The same can be said of a refabrication plant which accepts reprocessed fuel containing $0.1-0.2 \% \mathrm{Ru}, \mathrm{Nb}$, and $\mathrm{Zr}$.

\subsection{Operating}

The operating cost of the remote plant is higher than the fabrication plant because more direct labor is required to cope with the added complexity of the processes and maintenance.

\section{$5.3 \quad$ Combined Costs}

The capital and operating costs of a fabrication and refabrication plant with a throughput of 50,000 fuel elements have been published in References 2 and 3. This data, shown in Table 5-1, has been used to interpolate the approximate combined costs for a fabrication plant modified to take a gamma feed at various process locations, as shown in Figures 4-1 through 4-5. 
Table 5-1

SUMMARY OF CAPITAL. AND OPERATING COSTS BY PROCESS

IN \$ MILLIONS

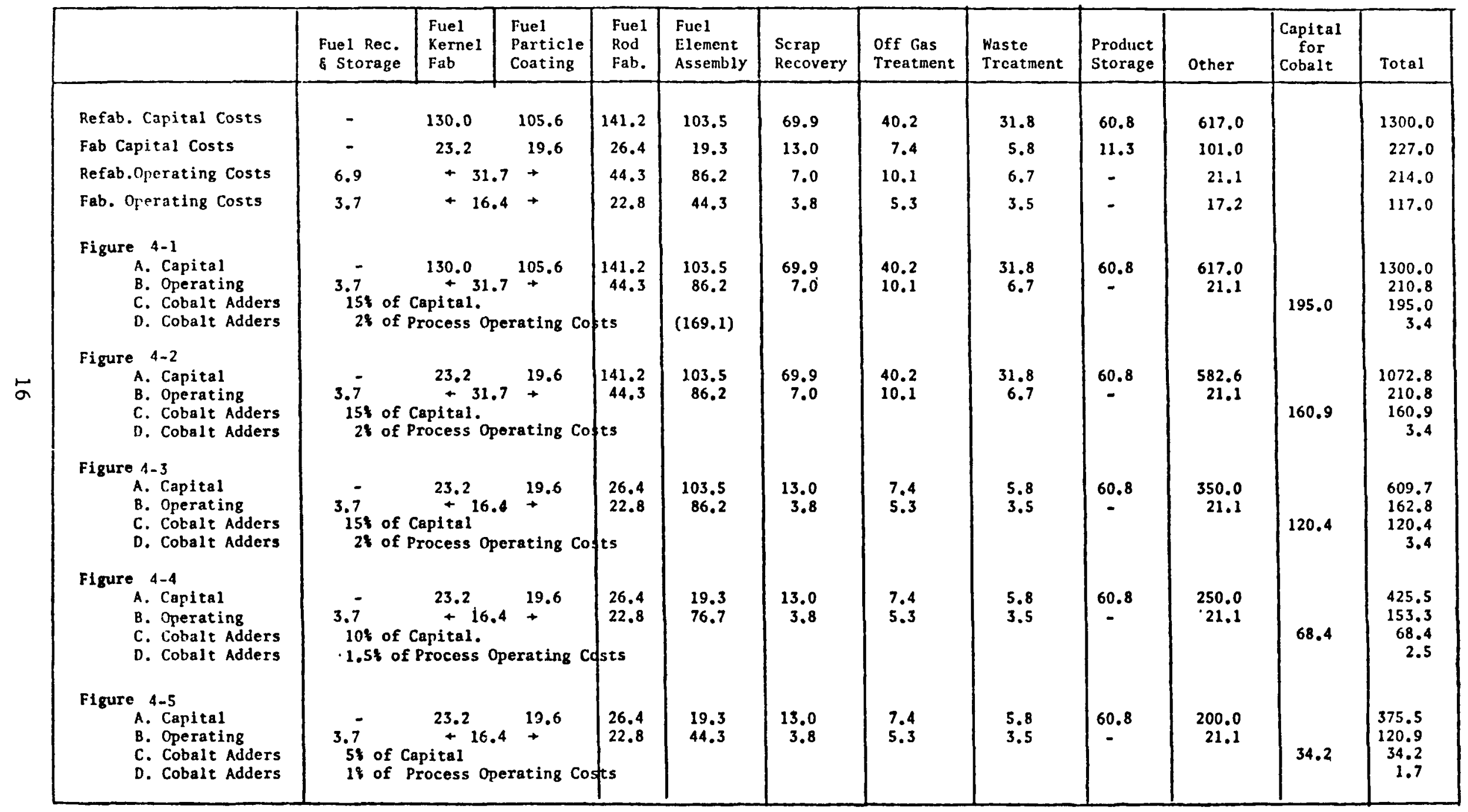

These numbers are the basic data and when multiplipd by numerous multipliers give the cost of the finished plant. 
The method of interpolation is as follows:

1) The capital cost for the fabrication facility was proportioned to each process as for the refabrication facility. This was done because the breakdown of total costs for the fabrication facility was not available but was available for the refabrication facility.

2) The operating costs of the fabrication facility were proportioned to each process as for the refabrication facility for the same reason as given in 1) above.

3) In the refabrication facility, all processes are considered remote. Therefore, any process that becomes remote through the introduction of $\mathrm{Co}-60$ (or $\mathrm{Ru}, \mathrm{Nb}$, and $\mathrm{Zr}$ ), at the fabrication facility is assumed to have capital and operating costs equal to that in a refabrication facility.

4) In Figures 4-1, 4-2 and 4-3, the additional facilities required because of Co-60 were assumed to increase the capital by $15 \%$ of the total capital costs. The extra operating cost was assumed to be $2 \%$ of the process operating costs.

5) In Figure 4-4, the additional facilities were assumed to increase the capital cost by only $10 \%$ of the total capital costs because a remote fuel disassembly cell is not required. The operating cost increase was assumed to be $1.5 \%$.

6) In Figure 4-5, the additional facilities were assumed to increase the capital costs by only $5 \%$ of the total capital cost because the remote load/unload cell and the cobalt waste storage cell are replaced by a simple 
"Attach Spikant" ce11. The operating cost increase was assumed to be $1 \%$.

7) In Figures 4-2, 4-3 and 4-4 the "Other" capital has been reduced successively by $6 \%$ because the facility becomes simpler.

8) In all cases, the capital and operating costs for fertile fabrication remain the same.

9) "Other" capital and operating costs are the non-process and support service costs.

The total cost data is summarized in Table 5-2. 
Table 5-2

SUMMARY OF TOTAL CAPITAL AND OPERATING COSTS

\begin{tabular}{|c|c|c|}
\hline & \multicolumn{2}{|c|}{$\$$ Millions } \\
\hline & Capital & Operating \\
\hline Refabrication & 1300 & 214 \\
\hline Co-60 mixed with feed $\mathrm{UO}_{2}$, Figure $4-1$ & 1495 & 214.2 \\
\hline Co-60 loaded into shim particles, Figure 4-2 & 1233.7 & 214.2 \\
\hline Co-60 rods placed at random, Figure $4-3$ & 730.1 & 166.2 \\
\hline Co-60 rods in specific fuel holes, Figure $4-4$ & 493.9 & 155.8 \\
\hline Co-60 rods attached, Figure $4-5$ & 409.7 & 122.6 \\
\hline Fabrication & 227 & 117 \\
\hline
\end{tabular}




\subsection{CONCLUSIONS}

1. It is evident that to keep costs to a minimum, the spikant should be an attachment to the fuel.

2. As the spikant is added nearer to the plant feed point, the capital and operating costs increase.

3. If the spikant is added with the uranium feed, the capital cost is more than for a refabrication plant, while the operating cost is a trifle less. 


\subsection{REFERENCES}

1. Dahlberg, R. C. et al., "HTGR Fuel and Fuel Cycle Summary Description", Report GA-A12801, January 1974.

2. Abraham, L., et. al., "Alternative Fuel Cycle Evaluation Program Fuel Cycle Characterization Study - HTGR Fabrication

- Plant," General Atomic Company Report GA-A15239, to be published.

3. Abraham, L. et. al., "Alternative Fuel Cycle Evaluation Program Fuel Cycle Characterization Study - HTGR Fabrication Plant," General Atomic Company Report GA-A15219, to be nublished. 


\section{APPENDIX 1}

Calculation of mass of Co-60 required.

The energy of the two gammas from Co-60 are:

$1.17 \mathrm{Mev}, 100 \%$ and $1.33,100 \%$ per disintegration

From Figure Al:

$$
\begin{aligned}
& 1.17 \mathrm{Mev} \equiv 4.8 \times 10^{5} \text { photons } / \mathrm{cm}^{2} \mathrm{sec} \\
& 1.33 \mathrm{Mev} \equiv 4.3 \times 10^{5} \text { photons } / \mathrm{cm}^{2} \mathrm{sec} .
\end{aligned}
$$

Then

$$
\frac{\mathrm{A}}{4.8 \times 10^{5}}+\frac{\mathrm{B}}{4.3 \times 10^{6}}=10 \mathrm{R} / \mathrm{hr}
$$

Where

$$
\begin{aligned}
& A=\text { gamma flux of } 1.17 \mathrm{Mev} \\
& B=\text { gamma flux of } 1.33 \mathrm{Mev}
\end{aligned}
$$

and since $A=B=100 \%$

$$
A=2.27 \times 10^{6} \text { photons } / \mathrm{cm}^{2} \mathrm{sec} .
$$




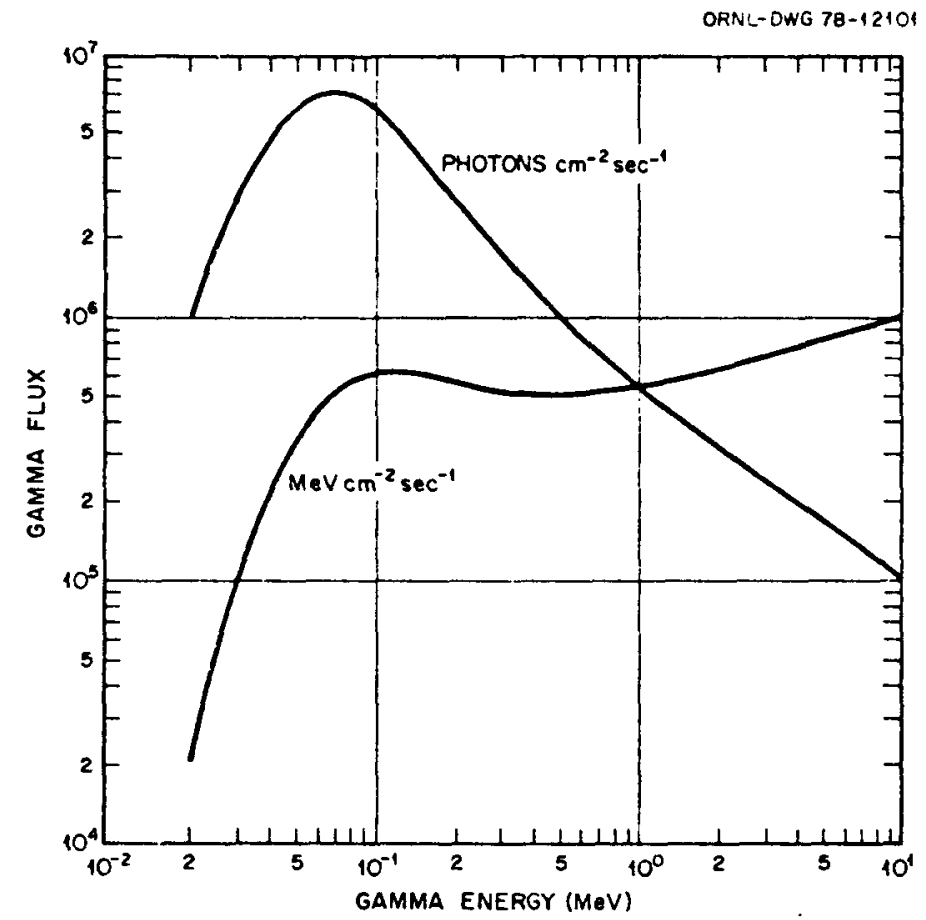

Fig. Al. Gamma Flux Equivalent to $1 \mathrm{R} / \mathrm{h}$ as a Function of Gamma Energy. From U.S. Department of Health, Education, and Welfare, Radiological Health Handbook, revised ed., September 1960, p. 140. 
Area at 1 meter round fuel element is given by:

$$
116 \times 2 \pi \times 80+4 \pi \times 116^{2}=2.27 \times 10^{5} \mathrm{~cm}^{2}
$$

Activity required in the fuel element to create $10 \mathrm{R} / \mathrm{hr}$ at 1 meter is:

$$
2.27 \times 10^{5} \times 2.27 \times 10^{6}=5.15 \times 10^{11} \text { decays } / \text { second } .
$$

This activity is required after 2 years of decay so the initial number of atoms of Co- 60 required is given by:

$$
\lambda N_{0} e^{-\lambda t}=5.15 \times 10^{11} \alpha / \mathrm{s}
$$

$$
\text { Where } \begin{aligned}
\lambda & =4.2 \times 10^{-9} \mathrm{~s}^{-1} \\
N_{0} & =\text { number of atoms Co-60 at } t=0 \\
t & =2 \text { years }
\end{aligned}
$$

Then $N_{0}=1.60 \times 10^{20}$ atoms of Co-60 initially

Mass of $\operatorname{Co}-60=0.016 \mathrm{~g}$ for $10 \mathrm{R} / \mathrm{hr}$ at 1 meter

But cobalt contains $2 \%$ of Co- 60 .

Hence, mass of cobalt required $/ \mathrm{FE}=0.80 \mathrm{~g}$ for $10 \mathrm{R} / \mathrm{hr}$ at 1 meter and $80 \mathrm{~g}$ for $1000 \mathrm{R} / \mathrm{hr}$ at 1 meter. 